\title{
Preliminary Measurement of Welding Fumes in Automotive Plants
}

\author{
Azian Hariri, A. Mutalib Leman, M. Zainal M. Yusof, N. Azreen Paiman, and Noraishah M. Noor
}

\begin{abstract}
The preliminary measurement of welding fumes was conducted by means to get firsthand experience and understanding the welding fumes issues in automotive assembly plant in Malaysia. Personal sampling pumps were provided to a human welder of highest risk in the assembly section. Series of direct reading measurement for area sampling of particulate matters $2.5 \mu \mathrm{m}$ or less in diameter size (P.M 2.5$)$, toxic gases and temperature were also conducted at the same time. The welding fumes sample were then analyze by scanning electron microscope with energy dispersive spectroscopy (SEM-EDS). Questionnaires were distributed to the welders for questionnaire's pilot test purpose in order to determine welder's knowledge on welding hazards and persistent symptom experience by each welder. Results of the study show that welding fumes contains the highest element of cobalt and nickel. Carbon monoxide $(\mathrm{CO})$, carbon dioxide $\left(\mathrm{CO}_{2}\right)$ and ammonia level were well below the standard level. Results from the mean score questionnaire analysis shows the welders posses limited knowledge of welding fumes hazard and not sure of the health effects of welding fumes There are eight persistent symptoms that had been experience by at least $50 \%$ of the welder. This preliminary study had successfully identified suggestion and alteration towards the actual measurement that will be conduct on the next stage.
\end{abstract}

Index Terms - Health symptoms, preliminary measurement, questionnaire, welding fumes.

\section{INTRODUCTION}

Welding process is one of the important processes in automotive industry. Welders in automotive industry engaged in welding works of a minimum eight hours per day and exposed towards many sorts of welding exposures. Currently, each welding workplace need to be monitored and

Manuscript received January 31, 2012; revised March 11, 2012. This work was supported in part by the Uni. Tun Hussein Onn Malaysia

Azian Hariri is currently doing her PhD in this subject under the Indoor Environment Research Group, Centre of Energy and Industrial Environment Studies, Uni. Tun Hussein Onn, Malaysia 86400, Johor Malaysia (e-mail: azian@uthm.edu.my).

A. Mutalib Leman is an Associate Professor in Industrial Hygiene, Department of Mechanical and Manufacturing Engineering, Uni. Tun Hussein Onn Malaysia 86400, Johor Malaysia (e-mail: mutalib@uthm.edu.my).

M.Zainal.M.Yusof is a Professor in Indoor Air Quality, Department of Aeronautics Engineering, Uni. Tun Hussein Onn Malaysia 86400, Johor Malaysia (e-mail: mdzainal@uthm.edu.my).

N. Azreen Paiman is doing her M.Eng in this subject under the Indoor Environment Research Group, Centre of Energy and Industrial Environment Studies, Uni. Tun Hussein Onn, Malaysia 86400, Johor Malaysia (e-mail: gd110160@ siswa.uthm.edu.my).

Noraishah M. Noor is a lecturer and committee of Research and Development Division with the International College of Automotive, 26607, Pahang Malaysia (e-mail: noraishah@icam.edu.my). evaluated to ensure the minimum level of exposure is maintained according to the standards in order to maintain a healthy and safe workplace. Welding fumes are solid particles that originate from welding consumables, the base metal and any coatings present on the base metal. In welding, the intense heat of the arc or flame vaporizes the base metal and/or electrode coating. This vaporized metal condenses into tiny particles called fumes that can be inhaled. The thermal effects can cause agglomeration of the particles into particle chains and clusters that can be deposited in the human respiratory tract [1]-[3].

\section{RELATED WORKS}

Current study on the effect of welding fume exposure to the welder in automotive industry had been conducted in many parts of the world including US, Taiwan and Iran [4-8]. These researchers had published proves of significant health risk of developing respiratory symptoms, decreasing pulmonary function, inflammatory responses, oxidation stress, airway irritation symptoms of workers working in automotive industry particularly when engaging with welding activities.

Despite the significant effect welding fumes to welders, the measurement of the welding emission is still within the allowable range of Occupational Safety and Health Association (OSHA) and American Conference and Governmental Industrial Hygienist (ACGIH) guidelines in the investigated automotive plant $[6,9]$.

Table I shows the selected number of occupational disease by causal agent and invalidity pension cases reported to Malaysian Social Security Organization (SOCSO) for the year 2007, 2008 and 2009 [10-12].

TABLE I: SElected OCCuPATIONAL Disease By CAUSAl AGENT AND INVALIDITY PENSION CASES REPORTED BY SOCSO FOR THE YEAR 2007, 2008 AND 2009 [10-12].

\begin{tabular}{|l|l|l|l|}
\hline Occupational disease by causal agent & 2007 & 2008 & 2009 \\
\hline Diseases due to copper or its compounds & 0 & 3 & 2 \\
\hline Diseases due to tin or its compounds & 0 & 1 & 1 \\
\hline Diseases due to zinc or its compounds & 1 & 0 & 2 \\
\hline Diseases due to irritants & 0 & 2 & 5 \\
\hline Diseases caused by manganese/toxic compounds & 0 & 1 & 1 \\
\hline Bronchopulmonary diseases caused by hard metal & 1 & 3 & 2 \\
\hline $\begin{array}{l}\text { Occupational asthma caused by sensitizing agents } \\
\text { or irritant inherent to the work process }\end{array}$ & 4 & 10 & 10 \\
\hline Invalidity pension cases reported & 2007 & 2008 & 2009 \\
\hline Malig. neoplasm of respiratory, intrathoracic & 22 & 52 & 46 \\
\hline Diseases of the upper respiratory tract & 41 & 26 & 30 \\
\hline Other diseases of the respiratory system & 189 & 175 & 126 \\
\hline
\end{tabular}


Although this statistic is in general and did not reflect directly to welders, the main concern would be the poor health status of workers were due to not knowing the causal agent of the disease in their working environment. Poor safety and health precaution lead to higher rates of occupational disease.

To this date, there is still very limited study that discussed the relationship between welding emissions with health risk of welder in automotive industry in Malaysia. Thus, this preliminary measurement was conducted to get basic experience and understanding on welding fumes issues in automotive assembly line. It is expected that better understanding of welding exposure in Malaysia automotive industry will be obtained in order to promote protection through legislation or health communications strategies where such data are needed.

\section{Methodology}

This preliminary study was conducted during a typical eight hours working shift from 8.00 a.m until 5.30 p.m with morning breaks from 10.00 to 10.20 a.m and lunch breaks from 1.00 to 2.00 p.m. The welding section consist of three assembly line; the front under, the body side and the main line. Within these three sections, one assembly line in the front under section considered as the highest risk area had been selected for this study. This is because it is located in the corner of the building far from main entrance and windows and also adjacent with the other two sections. There are five welders in this assembly line working with spot welding. All the welders were wearing protective gears such as safety boots, safety helmet, gloves, safety goggles, aprons and back supports. However none of the welders were using respirators during work. The welding workplace does not have any extractor but uses fan on each workstation by means of controlling welding fumes. Based on visual inspection, this welding workplace seems to be not highly polluted. Three main measurements conducted in this study are as follows:

\section{A. Personal Sampling}

The government accredited laboratory in Malaysia is the Industrial Hygiene Analytical Laboratory of the National Institute of Occupational Safety and Health (NIOSH), Malaysia. Currently this laboratory is capable of analyzing welding fumes sample using the atomic absorption spectrometry (AAS) equipment for scanning one metal element per sample as shown in Table II. The price per sample for one metal element analysis is range between RM 50 to RM 60. In order to enables the most efficient use of resources, a structured sampling and analysis approach should be arrange such as the preliminary analysis using SEM-EDS before conducting the actual measurement.

The filters media were analyzed by using scanning electron microscope with energy dispersive spectroscopy (SEM-EDS) to shortlist the metal elements exist in the sample. Jenkins and Eager [13] highlighted scanning electron microscope with energy dispersive spectroscopy (SEM-EDS) found to be effective techniques for evaluating the elemental composition of welding fumes after conducted a comparison study with inductively coupled mass spectroscopy (ICPMS), $\mathrm{X}$-ray fluorescence spectrometry (XRF), neutron activation analysis (NAA), X-ray induced photo electron spectrometry (XPS), X-ray diffraction (XRD) and transmission electron microscopy with energy dispersive spectroscopy (TEM EDS). Thus, it is also highlighted that the usage of SEM-EDS would be accurate only on particles size larger than half of micrometer size such as in this study.

TABLE II: LiST OF ANALYTICAL METHOD AVAILABLE FOR ANALYSIS

\begin{tabular}{llcc}
\hline No. & \multicolumn{1}{c}{ Chemical name } & $\begin{array}{c}\text { Analytical } \\
\text { method }\end{array}$ & $\begin{array}{c}\text { Analytical } \\
\text { Technique }\end{array}$ \\
\hline 1 & Arsenic & $\begin{array}{c}\text { NMAM 7900 } \\
{[14]}\end{array}$ & AAS \\
\hline 2 & Cadmium & $\begin{array}{c}\text { NMAM 7048 } \\
{[15]}\end{array}$ & AAS \\
\hline 3 & Chromium (total) & $\begin{array}{c}\text { NMAM 7024 } \\
{[16,17]}\end{array}$ & AAS \\
\hline 4 & Copper & $\begin{array}{c}\text { NMAM 7300 } \\
{[18]}\end{array}$ & AAS \\
\hline 5 & Ferum & $\begin{array}{c}\text { OSHA-ID 121 } \\
{[19]}\end{array}$ & AAS \\
\hline 6 & Lead & $\begin{array}{c}\text { NMAM 7105 } \\
{[20]}\end{array}$ & AAS \\
\hline 7 & Manganese & $\begin{array}{c}\text { OSHA ID -121 } \\
{[19]}\end{array}$ & AAS \\
\hline 8 & $\begin{array}{l}\text { Nickel / Zinc / Cobalt / } \\
\text { Aluminum }\end{array}$ & $\begin{array}{c}\text { NMAM 7300 } \\
{[18]}\end{array}$ & AAS \\
\hline
\end{tabular}

In favor of sampling method, one personal sampling pumps (Gillian 5000) were attached with 3 piece sampling cassette (SKC SureSeal) equipped with $37 \mathrm{~mm} 0.8 \mu \mathrm{m}$ mixed cellulose ester filter and supporting media according to suggested filters for welding fumes by NIOSH [21]. Each sampling pump was calibrated before and after each sampling using pump calibrator (TSI 4100 series).

The sampling pumps were set to $3 \mathrm{~L} / \mathrm{min}$ flow rate. One welder was chosen to wear the sampling pump based on their location in the assembly line (middle of the assembly line). The sampling cassette was attached to the neck collar in the breathing zone of the welders. The sampling was done from $8.00 \mathrm{a} . \mathrm{m}$ to 1.00 p.m to make sure the filter was not overloaded.

The filter was coated at $20 \mathrm{~mA}$ for 60 second with Platinum and mounted on the stubs SEM-EDS which were an adapted method from Antonini et. al [22]. The filter was divided into 4 equal sections and on each section, a middle point was selected plus one more point approximately in the middle of the filters were selected for analyze. Total of 5 points were analyzed by the SEM-EDS to shortlisted the metal elements that exists in the samples.

\section{B. Area Sampling}

Area sampling for toxic gases, temperature and particulate matters $2.5 \mu \mathrm{m}$ or less in diameter size (P.M $\left.{ }_{2.5}\right)$ were done by using a direct reading instrument (Graywolf Toxic Gas Monitor TG 501, Graywolf Indoor Air Quality Meter IQ-410, TSI-Dustrak,). The instruments were located at the middle of the selected assembly line approximately $150 \mathrm{~cm}$ from the floor [23]. The measurements were done directly from 8.00 a.m to 5.30 p.m with interval time were set to 1 minutes.

\section{Questionnaire's Pilot Test}

Set of questionnaire were drafted to seek information from 
welders in term of;

1) Welders basic knowledge of welding workplace hazard

2) Welders basic knowledge on health risk of welding fumes

3) Welders desire to know their health risk in the current workplace

4) Persistent symptom experience by the welders for the past 3 months

The questionnaires pertaining to persistent symptoms were developed by first listing out the health symptoms from Material Safety Data Sheet (MSDS) from NIOSH Pocket Guide to Chemical Hazards [24] according to metal elements that can be analyzed by NIOSH certified laboratory as outline in Table 1. These listed health symptoms were then crossed reference to American Thoracic Society and The Division of Lung Diseases(ATS-DLD-78)[25], The International Union against Tuberculosis and Lung Disease (IUATLD) Bronchial Symptoms Questionnaire [26], Quick Environmental Exposure and Sensitivity Inventory (QEESI) [27], NIOSH Indoor Air Quality Questionnaire [28] and Indoor Climate Questionaire-MM040 EA [29]. Finally only 19 health symptoms were shortlisted for this questionnaire.

The questionnaires on persistent symptoms were then translate to Malay language by fluent speaker and try out with 2 to 4 native speakers. The questionnaires were translated back to its original language using certified translator. In favor of pilot test purpose, these questionnaires were distributed to all the welders during the beginning of the work and were collected at the end of the work shift.

\section{RESULTS AND DISCUSSIONS}

\section{A. Personal Sampling}

Results of the SEM-EDS analysis of selected five points in the filters are as shown in Table III. From the 11 element tested, cobalt and nickel have significant value of mass (\%) for all point tested. Thus, an actual measurement should consider for these two elements.

TABLE III: METAL ELEMENT ANALYSIS USING SEM-EDS

\begin{tabular}{lcccccc}
\hline Metal & \multicolumn{5}{c}{ Mass (\%) } \\
Elements & Point & Point & Point & Point & Point & Avg. \\
& 1 & 2 & 3 & 4 & 5 & \\
Aluminium & 0.12 & 0.02 & 0 & 0 & 0.01 & 0.03 \\
Chromium & 1.71 & 2.17 & 1.79 & 3.00 & 2.25 & 2.18 \\
Manganese & 0.08 & 0.27 & 0.01 & 0 & 0.02 & 0.08 \\
Ferum & 0.20 & 0 & 0 & 0.46 & 0.39 & 0.21 \\
Cobalt & 39.72 & 39.5 & 39.81 & 39.23 & 39.07 & 39.46 \\
Nickel & 43.87 & 43.35 & 43.82 & 41.86 & 42.38 & 43.05 \\
Copper & 6.21 & 6.48 & 6.36 & 6.07 & 6.37 & 6.30 \\
Zinc & 6.66 & 7.35 & 6.99 & 6.46 & 7.39 & 6.97 \\
Arsenic & 0 & 0 & 0 & 0.63 & 0.29 & 0.18 \\
Cadmium & 0 & 0.12 & 0.2 & 0 & 0 & 0.06 \\
Lead & 1.44 & 0.73 & 1.01 & 2.29 & 1.84 & 1.46 \\
\hline
\end{tabular}

Short listing of elements need to be done because each metal elements required different method of sampling and analysis. Particularly the minimum/maximum volume and flow rate which directly will also influence the sampling time.

\section{B. Area Sampling}

Data for toxic gases (ammonia, sulfur dioxide, nitric oxide, nitrogen dioxide, carbon monoxide, carbon dioxide), $\mathrm{PM}_{2.5}$ and temperature were taken continuously for the whole work shift as shown in Table IV. There are no traces of sulfur dioxide, nitric oxide and nitrogen dioxide found during the whole work shift. Temperatures were slightly higher during lunch breaks due to the fans were stopped during that time resulting a high concentration of carbon dioxide although the assembly line were empty during lunch breaks. Traces of ammonia and P.M 2.5 were low and well below the prevailing standards. This also confirm that the personal sampling of fumes will not be affect by others source of contaminants.

TABLE IV: DATA FOR TOXIC GASES, PM $_{2.5}$ AND TEMPERATURE

\begin{tabular}{|c|c|c|c|}
\hline \multicolumn{4}{|c|}{ Morning session (8.00 a.m to 1.00 p.m) } \\
\hline parameter & $\min$ & average & $\max$ \\
\hline temp & 27.2 & 29.1 & 31 \\
\hline P.M 2.5 & $\mathbf{0}$ & 0.1 & 0.2 \\
\hline ammonia & 0.6 & 1.2 & 2.3 \\
\hline sulfur dioxide & $\mathbf{0}$ & $\mathbf{0}$ & $\mathbf{0}$ \\
\hline nitric oxide & $\mathbf{0}$ & $\mathbf{0}$ & $\mathbf{0}$ \\
\hline nitrogen dioxide & $\mathbf{0}$ & $\mathbf{0}$ & $\mathbf{0}$ \\
\hline carbon monoxide & $\mathbf{0}$ & 0.1 & 0.4 \\
\hline carbon dioxide & 491.0 & 521.2 & 622.0 \\
\hline \multicolumn{4}{|c|}{ Lunch hour (1.00 p.m to 2.00 p.m) } \\
\hline parameter & $\min$ & average & $\max$ \\
\hline temp & 31.4 & 31.9 & 32.4 \\
\hline P.M 2.5 & $\mathbf{0}$ & $\mathbf{0}$ & 0.1 \\
\hline ammonia & 0.6 & 0.7 & 0.8 \\
\hline sulfur dioxide & $\mathbf{0}$ & $\mathbf{0}$ & $\mathbf{0}$ \\
\hline nitric oxide & $\mathbf{0}$ & $\mathbf{0}$ & $\mathbf{0}$ \\
\hline nitrogen dioxide & $\mathbf{0}$ & $\mathbf{0}$ & $\mathbf{0}$ \\
\hline carbon monoxide & $\mathbf{0}$ & $\mathbf{0}$ & $\mathbf{0}$ \\
\hline carbon dioxide & 491.0 & 500.2 & 543.0 \\
\hline \multicolumn{4}{|c|}{ Afternoon session ( 2.00 p.m to 5.30 p.m) } \\
\hline parameter & $\min$ & average & $\max$ \\
\hline temp & 30.2 & 31 & 31.6 \\
\hline P.M 2.5 & $\mathbf{0}$ & 0.1 & 0.2 \\
\hline ammonia & 0.7 & 1.0 & 1.3 \\
\hline sulfur dioxide & $\mathbf{0}$ & $\mathbf{0}$ & $\mathbf{0}$ \\
\hline nitric oxide & $\mathbf{0}$ & $\mathbf{0}$ & $\mathbf{0}$ \\
\hline nitrogen dioxide & $\mathbf{0}$ & $\mathbf{0}$ & $\mathbf{0}$ \\
\hline carbon monoxide & $\mathbf{0}$ & $\mathbf{0}$ & $\mathbf{0}$ \\
\hline carbon dioxide & 482.0 & 493.7 & 576.0 \\
\hline
\end{tabular}

\section{Questionnaire}

20 sets of questionnaires were distributed to all the welders before the work shift start and they were told to answer and returned the questionnaire before the end of the work shift. Only 11 out of 20 sets of questionnaire were returned back.

Welders were asked to choose within a 5 point Likert scale for each question as shown in Table V. 
TABLE V: QUESTIONNAIRE SCORE AND CRITERIA

\begin{tabular}{c|ll}
\hline Score & & Criteria \\
\hline 5 & very familiar & really want to know \\
4 & familiar & want to know \\
3 & not sure & not sure \\
2 & unfamiliar & do not want to know \\
1 & very unfamiliar & really do not want to know \\
\hline
\end{tabular}

According to the mean score calculated, the mean criteria were interpreted as shown in Table VI.

TABLE VI: QUESTIONNAIRE MEAN CRITERIA

\begin{tabular}{c|c|ll}
\hline \multicolumn{2}{c|}{ Mean Score } & \multicolumn{2}{c}{ Mean Criteria } \\
\hline Min & Max & & \\
\hline 4.21 & 5 & very familiar & really want to know \\
3.41 & 4.2 & familiar & want to know \\
2.61 & 3.4 & not sure & not sure \\
1.81 & 2.6 & unfamiliar & do not want to know \\
1 & 1.8 & very unfamiliar & really do not want to know \\
\hline
\end{tabular}

In the first question, welders were asked on their basic knowledge of welding hazard. $80 \%$ to $90 \%$ of the welders were familiar with particulate matters/dust hazard and noise hazard. The lowest, only $18.2 \%$ of the workers were aware of the metal fumes hazard cause by welding operation. Overall, the welders were not sure on the hazard of toxic gases, metal fumes and radiation/heat but familiar with particulate matters/ dust and noise hazard as shown in Table VII.

TABLE VII: QUESTIONNAIRE ANALYSIS ON TYPE OF WELDING HAZARD

\begin{tabular}{|c|c|c|c|c|c|}
\hline \multirow[t]{2}{*}{$\begin{array}{c}\text { Type of } \\
\text { welding } \\
\text { hazard }\end{array}$} & $\begin{array}{c}\text { Very } \\
\text { familiar } \\
\text { and } \\
\text { familiar }\end{array}$ & $\begin{array}{l}\text { Not } \\
\text { sure }\end{array}$ & $\begin{array}{l}\text { Unfamiliar } \\
\text { and very } \\
\text { unfamiliar }\end{array}$ & \multirow[t]{2}{*}{$\begin{array}{l}\text { Mean } \\
\text { score }\end{array}$} & \multirow[t]{2}{*}{$\begin{array}{c}\text { Mean } \\
\text { Criteria }\end{array}$} \\
\hline & $\%$ & $\%$ & $\%$ & & \\
\hline Toxic gas & 27.3 & 27.3 & 45.5 & 2.73 & Not sure \\
\hline Metal Fumes & 18.2 & 45.5 & 36.4 & 2.73 & Not sure \\
\hline $\begin{array}{l}\text { Radiation/ } \\
\text { Heat }\end{array}$ & 27.3 & 27.3 & 45.5 & 2.82 & Not sure \\
\hline $\begin{array}{l}\text { Particulates } \\
\text { Matters/Dust }\end{array}$ & 90.9 & 9.1 & 0.0 & 4.09 & Familiar \\
\hline Noise & 81.8 & 18.2 & 0.0 & 4.00 & Familiar \\
\hline
\end{tabular}

Table VIII shows the analysis of the second question to get information on welders' basic knowledge of health risk cause by welding fumes exposure. Overall, the welders were familiar of the listed health risk except for systemic toxins, neurotoxins, reproductive toxins and carcinogen.

When asked the third question on the welders desire to know the health risk exists in their current workplace, all of them agreed to 'want to know' as shown in Table 9. However, there was a high percentage of the welders who select 'not sure' mainly because they were not familiar of the listed health risk rather than 'not sure' to want to know or do not want to know the health risk exist in their current workplace. It is suggested that 'not sure' should be dropped from the answer list in the actual questionnaire to get accurate data portraying the welders' desire.
TABLE VIII: QUESTIONNAIRE ANALYSIS ON HEALTH RISK

\begin{tabular}{|l|c|c|c|c|c|}
\hline \multirow{2}{*}{$\begin{array}{c}\text { Health risk } \\
\begin{array}{c}\text { welding fumes } \\
\text { exposure }\end{array}\end{array}$} & $\begin{array}{c}\text { Very } \\
\text { familiar } \\
\text { and } \\
\text { familiar }\end{array}$ & $\begin{array}{c}\text { Not } \\
\text { sure }\end{array}$ & $\begin{array}{c}\text { Unfamiliar } \\
\text { and very } \\
\text { unfamiliar }\end{array}$ & $\begin{array}{c}\text { Mean } \\
\text { score }\end{array}$ & $\begin{array}{c}\text { Mean } \\
\text { Criteria }\end{array}$ \\
\cline { 2 - 5 } & $\%$ & $\%$ & $\%$ & 3.73 & Familiar \\
\hline Irritants & 63.6 & 36.4 & 0 & 3.82 & Familiar \\
\hline Sensitizer & 81.8 & 18.2 & 0 & 3.91 & Familiar \\
\hline Respiratory & 81.8 & 18.2 & 0 & 3.00 & Not sure \\
\hline Systemic Toxins & 18.2 & 63.6 & 18.2 & 2.91 & Not sure \\
\hline Neurotoxins & 18.2 & 54.5 & 27.3 & 3.00 & Not sure \\
\hline $\begin{array}{l}\text { Reproductive } \\
\text { Toxins }\end{array}$ & 27.3 & 45.5 & 27.3 & 2.91 & Not sure \\
\hline Carcinogen & 9.1 & 72.7 & 18.2 & 3.55 & Familiar \\
\hline Mixture Effects & 63.6 & 27.3 & 9.1 & & \\
\hline
\end{tabular}

TABLE IX: QUESTIONNAIRE ANALYSIS ON WELDERS DESIRE TO KNOW THE HEALTH RISK EXISTS IN THE CURRENT WORKPLACE

\begin{tabular}{|l|c|c|c|c|c|}
\hline \multicolumn{1}{|c|}{$\begin{array}{c}\text { Desire to } \\
\text { know the } \\
\text { health risk } \\
\text { exist in the } \\
\text { current } \\
\text { workplace }\end{array}$} & $\begin{array}{c}\text { Really } \\
\text { want to } \\
\text { know and to } \\
\text { know }\end{array}$ & $\begin{array}{c}\text { Not } \\
\text { sure }\end{array}$ & $\begin{array}{c}\text { Do not want } \\
\text { to know and } \\
\text { really do } \\
\text { not want to } \\
\text { know }\end{array}$ & $\begin{array}{c}\text { Mean } \\
\text { score }\end{array}$ & $\begin{array}{c}\text { Mean } \\
\text { Criteria }\end{array}$ \\
\cline { 2 - 5 } Irritants & 81.8 & 18.2 & 0.0 & 4.00 & $\begin{array}{c}\text { Want to } \\
\text { know }\end{array}$ \\
\hline Sensitizer & 81.8 & 18.2 & 0.0 & 3.91 & $\begin{array}{c}\text { Want to } \\
\text { know }\end{array}$ \\
\hline Respiratory & 90.9 & 9.1 & 0.0 & 4.09 & $\begin{array}{c}\text { Want to } \\
\text { know }\end{array}$ \\
\hline $\begin{array}{l}\text { Systemic } \\
\text { Toxins }\end{array}$ & 54.5 & 36.4 & 9.1 & 3.64 & $\begin{array}{c}\text { Want to } \\
\text { know }\end{array}$ \\
\hline Neurotoxins & 54.5 & 45.5 & 0.0 & 3.64 & $\begin{array}{c}\text { Want to } \\
\text { know }\end{array}$ \\
\hline $\begin{array}{l}\text { Reproductive } \\
\text { Toxins }\end{array}$ & 63.6 & 36.4 & 0.0 & 3.73 & $\begin{array}{c}\text { Want to } \\
\text { know }\end{array}$ \\
\hline Carcinogen & 54.5 & 45.5 & 0.0 & 3.64 & $\begin{array}{l}\text { Want to } \\
\text { know }\end{array}$ \\
\hline $\begin{array}{l}\text { Mixture } \\
\text { Effects }\end{array}$ & 72.7 & 27.3 & 0.0 & 3.91 & $\begin{array}{c}\text { Want to } \\
\text { know }\end{array}$ \\
\hline
\end{tabular}

In the questionnaire on persistent symptoms, the welders were asked to answer how frequent each of the health symptoms is experience for the past 3 months. Persistent symptom were define as health symptoms questions answered by the welders by 'yes, every time after doing welding works', 'yes, sometimes (every week)'and 'yes, occasionally'. From the analysis, 8 symptoms were analyzed as being experience by at least $50 \%$ of the welders. The symptoms are fatigue or unusual tiredness, stuffy or runny nose, headache, difficulties concentrating or remembering things, burning or irritation of the eyes, sore or dry throat, problem with body balance and coordination and problem with numbness and tingling on part of body. Also, at least $50 \%$ of the welders agreed that 15 health symptoms out of 19 health symptoms were caused by their working environment as shown in Fig. 1.

The main concern of this persistent symptoms questionnaire is on the verification method of the questionnaire results weather it's represent the underlying true health symptoms experience by the welder. There are difficulties in acquiring the medical record of the welders since no complete medical records were available and kept with the companies. Sick leave and absenteeism from work cannot be use as a verification reference as the information 
could be misleading. In order to verify the health symptom experience by the welders, spirometry test for lung function analysis were suggested for verification purpose when conducting the actual measurement on the next stage.

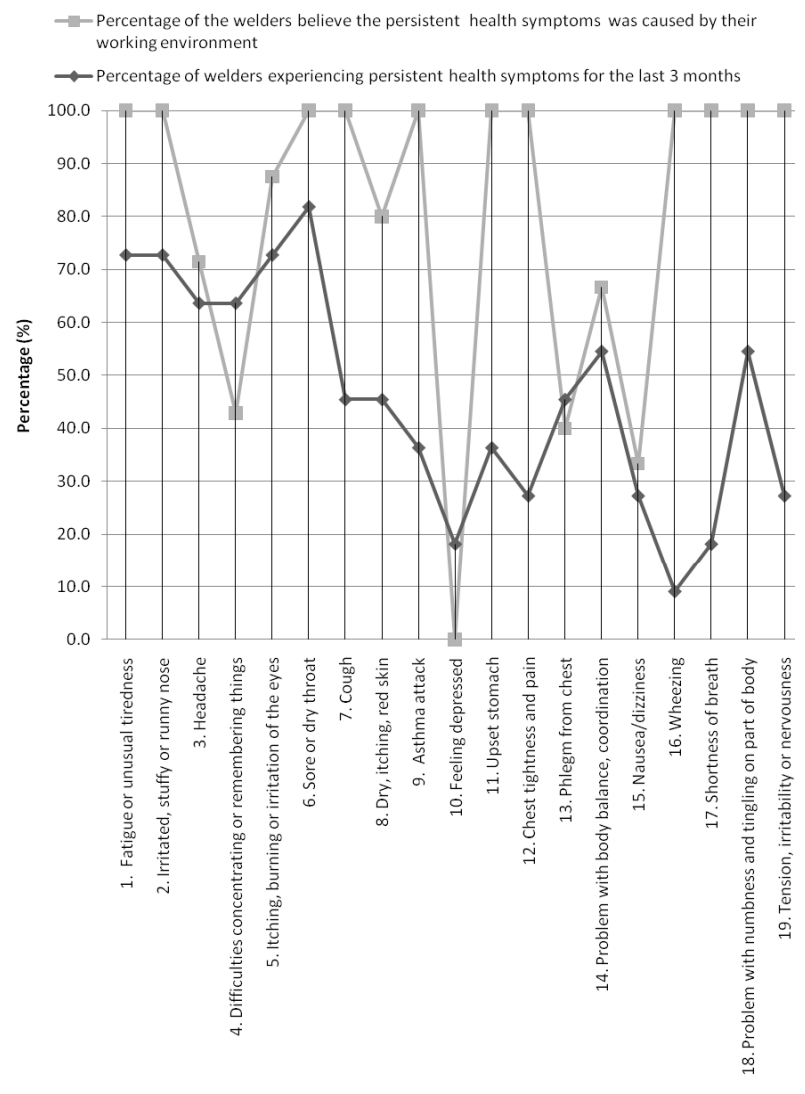

Health Symptom

Fig.1. Health symptom analysis

\section{CONCLUSIONS}

Preliminary study had successfully identified valuable suggestion and alteration that need to be considered during the actual measurement in the next stage of work. Limitation on type of analytical method for analyzing metal fumes by certified NIOSH laboratory brought us to the preliminary analysis of welding fumes samples by using SEM-EDS. SEM-EDS were used to identify and shortlist the main metal element contain in the filter. This is crucial since different metal elements have different standard sampling methods which require different flow rate, different minimum/maximum volume and different sampling time. SEM-EDS preliminary analysis enables the most efficient use of resources since a sample cost around RM 50-RM60 to be analyzed by NIOSH analytical laboratory.

Toxic gases and $\mathrm{PM}_{2.5}$ measurement results although did not show significant finding in this preliminary measurement, the data shows that there were no other source of contaminant in the workplace that could affect the personal sampling of the welding fumes.

In the questionnaire, questions on the welders desire to 'want to know' or 'do not want to know' the health risk that exists in their current workplace should not include the 'not sure' answer. This could give the wrong impression about the welders opinion especially if the welders are not familiar with the health risk stated in the questionnaire.
The results of the persistent symptoms questionnaires were difficult to be verified since the company does not kept complete medical record of all the welders. Sick leaves information from panel clinic could be misleading and difficult to acquire due to confidentiality between the clinics and workers. Thus, spirometry test for lung function analysis to detect lung impairment should be carried out during the actual measurement stage as means of verification method of the persistent symptoms questionnaires.

\section{ACKNOWLEDGMENT}

The authors would like to express our gratitude to the automotive company for allowing us to conduct this preliminary study. The authors also would like to thank all the welders for spending their precious time taking part in this study. We also like to thank Mr. Mohd. Tarmizi Nasir, technician of SEM-EDS in Universiti Tun Hussein Onn Malaysia for his valuable guidance and support.

\section{REFERENCES}

[1] H. S. Ashby, "Welding Fumes in the Workplace: Preventing Potential Health Problems Through Proactive Controls," Professional Safety, pp. 55-60, 2002.

[2] S. R. Fiore, "Reducing Exposure to Hexavalent Chromium in Welding Fumes," Welding Journal, pp. 38-43, August 2006.

[3] E. Ravert, "Controlling Chromium Fumes," Welding Journal, November 2006.

[4] E. Kiesswetter, et al., "Longitudinal Study on Potential Neurotoxic Effects of Aluminium: II. Assessment of Exposure and Neurobehavioral Performance Of Al Welders In The Automobile Industry Over 4 Years," International Archives of Occupational and Environmental Health, vol. 82, no. 10, pp. 1191-1210, 2009.

[5] R.W. Kobrosly, J. R. Meliker, and J. O. Nriagu, "Automobile Industry Occupations and Bladder Cancer: A Population-Based Case-Control Study in Southeastern Michigan, USA," Occupational and Environmental Medicine, vol. 66, no. 10, pp. 650-656, 2009.

[6] Z. Loukzadeh, et al., "Pulmonary Effects of Spot Welding in Automobile Assembly," Occupational Medicine, vol. 59, no. 4, pp. 267-269, 2009.

[7] J. C. J. Luo, K. H. Hsu, and W. S. Shen, "Pulmonary Function Abnormalities and Airway Irritation Symptoms of Metal Fumes Exposure on Automobile Spot Welders," American Journal of Industrial Medicine, vol. 49, no. 6, pp. 407-416, 2006.

[8] J.-C. J. Luo,, K.-H. Hsu, and W.-S. Shen, "Inflammatory Responses and Oxidative Stress From Metal Fume Exposure in Automobile Welders," Journal of Occupational and Environmental Medicine, vol. 51, no. 1, pp. 95-103, 2009.

[9] J. Dasch and J. D'Arcy, "Physical and Chemical Characterization of Airborne Particles from Welding Operations in Automotive Plants," Journal of Occupational and Environmental Hygiene, vol. 5, no. 7, pp. 444 - 454, 2008.

[10] SOCSO, Annual Report. 2007.

[11] SOCSO, Annual Report. 2008.

[12] SOCSO, Annual Report. 2009.

[13] N. T. Jenkins and T. W. Eager, "Chemical Analysis of Welding Fume Particles," Welding Journal, pp. 87-93, June 2005.

[14] NIOSH, Arsenic and compound, as As, in NIOSH Manual of Analytical Methods, M. 7900, Editor. 1994.

[15] NIOSH, Cadmium and compounds, as Cd, in NIOSH Manual of Analytical Methods, M. 7048, Editor. 1994.

[16] NIOSH, Chromium and compound, $\mathrm{Cr}$, in NIOSH Manual of Analytical Methods, M. 7024, Editor. 7024.

[17] NIOSH, Chromium and compound, Cr, in NIOSH Manual of Analytical Methods, M. 7024, Editor. 1994.

[18] NIOSH, Elements by ICP, in NIOSH Manual of Analytical Methods, M. 7300, Editor. 2003.

[19] OSHA, Metal \& Metalloid Particulates in Workplace Atmospheres (Atomic Absorbtion), in OSHA Analytical Methods, M. ID-121, Editor. 2002 . 
[20] NIOSH, Lead by GFAAS, in NIOSH Manual of Analytical Methods, M. 7105, Editor. 1994.

[21] M. DOSH, "Guidelines on Monitoring of Airborne Contaminant for Chemicals Hazardous to Health," 2005.

[22] J. M. Antonini, et al., "Design, Construction, and Characterization of a Novel Robotic Welding Fume Generator and Inhalation Exposure System for Laboratory Animals," Journal of Occupational and Environmental Hygiene, vol. 3, no. 4, pp. 194-203, 2006.

[23] ACGIH, Industrial Ventilation: A Manual of Recommended Practise 1998.

[24] NIOSH, NIOSH Pocket Guide to Chemical Hazards. 2007.

[25] B. G. Ferris, "Epidemiology Standardization Project. II. Recommended Respiratory Disease Questionnaires for Use With Adults and Children in Epidemiological Research," Am Rev Respir Dis, 1978.

[26] P. G. Burney, et al., "Validity and Repeatability of the IUATLD (1984) Bronchial Symptoms Questionnaire: An International Comparison," European Respiratory Journal, vol. 2, no. 10, pp. 940-945, 1989.

[27] C. Miller and T. Prihoda, "The Environmental Exposure and Sensitivity Inventory (EESI): A Standardized Approach for Measuring Chemical Intolerances for Research and Clinical Applications," Toxicol Ind Health 15(3-4): pp. 370-385, 1999.
[28] D. K. Nims, "Basics of Industrial Hygiene," 1999, Canada: John Wiley and Sons Inc.

[29] K. Anderson, et al., "Questionnaire as an Instrument When Evaluating Indoor Climate," Healthy Building, 1988. 3: p. 139-145.

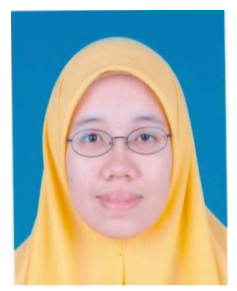

Azian Hariri was born in Perak, Malaysia on 27 August 1978. Holds a B.Eng (Mechanical) from University of Fukui, Japan in 2002 and M.Eng (Mechanical) from Universiti Tun Hussein Onn Malaysia, Batu Pahat, Johor in 2009. She had experience working in Electronics Company as a mechanical engineers for one years before appointed as an Instructor Engineer at Faculty of Engineering Technology, University College of Tun Hussein Onn Malaysia. She is now a lecturer in Department of Plant and Automotives, Faculty of Mechanical and Manufacturing Engineering, Universiti Tun Hussein Onn Malaysia, Batu Pahat, Johor and on study leave for a PhD. at the same institution. Current research interests include Indoor Environment Quality, Industrial Hygiene and Occupational Safety and Health. 